\title{
ANALISIS PENILAIAN KINERJA KEUANGAN PADA DANA PENSIUN UNIVERSITAS SURABAYA
}

\author{
Diah Anugrah Sharasanti* \\ diahsharasanti@yahoo.com \\ Ratnawati HP* \\ budi2012@yahoo.com
}

\begin{abstract}
In accordance with the Act of Pension Fund, Number 11 of 1992, the participant fee is one of the pension fund assets which should be managed in line with the investment guideline outlined by the founder and investment regulation set by the ministry. The financial performance can be assessed by comparing the finance ration and the standard ratio. In addition, it can be evaluated by comparing the finance ratio of the current year and the fiancé ratio of the previous years. This research was aimed at analyzing the financial performance of the pension fund. The subject of this research is the Pension Fund of University of Surabaya, a pension fund from the employer with fixed benefits for participants and the parties entitled. The measurement of the financial performance was conducted for the financial statement of 2011 to 2016 and it refers to the ratio of the performance evaluation of the pension fund ADPI, that is, calculating and analyzing the ratio of ROI, Operating Cost Efficiency, Investment Cost Efficiency, Fund Sufficiency Ratio, Pension fund growth ratio. The result of the study showed that the financial performance of pension fund of University of Surabaya was categorized as "good" and ranked as level one quality.
\end{abstract}

Keywords: pension fund, financial peroformance.

\section{Pendahuluan}

Dalam rangka memberikan jaminan kesejahteraan pada karyawan, dana pensiun merupakan salah satu alternatif yang diberikan oleh perusahaan ketika karyawannya telah memasuki usia pensiun.
Menurut Pernyataan Standar Akuntansi Keuangan (PSAK) No. 18 tentang Akuntansi Dana Pensiun, dana pensiun adalah badan hukum yang mengelola dan menjalankan program yang menjanjikan manfaat pensiun. Manfaat pensiun adalah pembayaran

\footnotetext{
* Dosen Program Studi Akuntansi Politeknik Ubaya, Surabaya
} 
berkala yang dibayarkan kepada peserta pada saat dan dengan cara yang ditetapkan dalam peraturan dana pensiun (PSAK 24). Artinya, manfaat pensiun merupakan besarnya penghasilan yang akan diterima karyawan ketika memasuki masa pensiun yang dibayar oleh perusahaan dana pensiun, berdasarkan perhitungan tertentu.

Dari kedua pengertian di atas dapat disimpulkan bahwa dana pensiun akan mengelola uang yang diperoleh dari iuran peserta program pensiun, dan mempunyai kewajiban untuk membayarkan kembali ketika peserta program pensiun memasuki masa pensiun. Kewajiban tersebut menuntut dana pensiun mengelola keuangannya secara optimal untuk mendapatkan suatu hasil yang maksimal. Pengelolaan keuangan oleh dana pensiun diatur di dalam UndangUndang Nomor 11 tahun 1992 tentang Dana Pensiun. Peran dari undang-undang ini adalah sebagai bentuk perlindungan yang diberikan oleh pemerintah agar pengelolaan iuran dana pensiun dapat diatur dengan sebaik mungkin tanpa ada yang dirugikan.

Menurut Undang-Undang Nomor 11 tahun 1992, iuran dari peserta adalah salah satu bagian dari kekayaan dana pensiun yang harus dikelola sesuai dengan arahan investasi yang digariskan oleh pendiri dan ketentuan investasi yang ditetapkan oleh Menteri. Dengan kata lain, iuran tersebut harusdiinvestasikankedalamproduk-produk investasi yang telah ditetapkan dan diatur dalam perundangan, sehingga mendapatkan hasil yang akan dibagikan kembali kepada peserta pensiun. Menurut Peraturan Jasa Otoritas Keuangan Nomor 3/POJK.05/2015 tentang Investasi Dana Pensiun, terdapat 17 (tujuh belas) jenis investasi yang boleh ditempatkan dana pensiun, yaitu tabungan, deposito, sertifikat deposito, surat berharga Bank indonesia, surat berharga negara, saham yang tercatat di Bursa Efek Indonesia (BEI), obligasi, reksadana, efek beragun aset,
MTN, dana investasi real estat berbentuk kontrak investasi kolektif, kontrak opsi dan berjangka efek yang diperdagangkan di BEI, REPO, penyertaan langsung baik di Indonesia maupun di luar negeri, tanah di Indonesia, dan bangunan di Indonesia. Dikarenakan investasi adalah komponen pokok di dalam penyelenggaraan usaha dana pensiun, maka kinerja dari dana pensiun sangat penting untuk diukur sebagai bentuk pertanggungjawabannya kepada berbagai pihak yang berkepentingan. Selain itu, pengukuran kinerja keuangan adalah salah satu bentuk evaluasi terhadap kemampuan pengurus dana pensiun di dalam mengelola keuangannya. Kinerja keuangan dapat dinilai dengan membandingkan rasio keuangan dengan standar rasio. Selain itu, kinerja keuangan juga dapat dinilai dengan membandingkan rasio keuangan tahun yang dinilai dengan rasio keuangan pada tahuntahun sebelumnya. Dengan membandingkan rasio keuangan pada beberapa tahun penilaian dapat dilihat bagaimana kemajuan ataupun kemunduran kinerja keuangan sesuai dengan kegunaan masing-masing rasio tersebut (Munawir, 2010).

Menurut Asosiasi Dana Pensiun Indonesia (ADPI), penilaian kinerja keuangan dana pensiun dapat diukur melalui indikator rasio kinerja keuangan, yaitu Return On Investment (ROI), Efisiensi Biaya Operasional (EBO), Efisiensi Biaya Investasi (EBI), dan Rasio Kecukupan Dana (RKD). Indikatorindikator tersebut digunakan ADPI untuk menentukan dana pensiun yang memiliki kinerja terbaik, dan akan ditetapkan setiap tahun untuk diberi penghargaan.

Berdasarkan uraian di atas, penulis tertarik untuk melakukan analisis terhadap kinerja keuangan dari dana pensiun. Obyek penelitian yang dipilih adalah Dana Pensiun Universitas Surabaya (Ubaya), yang merupakan dana pensiun pemberi kerja 
yang menyelenggarakan program pensiun manfaat pasti bagi peserta dan pihak yang berhak. Pengukuran kinerja keuangan dilakukan pada Laporan Keuangan Periode 2011 sampai dengan 2016, dan mengacu pada rasio penilaian kinerja dana pensiun oleh ADPI, yaitu menghitung dan menganalisis rasio Return On Investment (ROI), Efisiensi Biaya Operasional (EBO), Efisiensi Biaya Investasi (EBI), Rasio Kecukupan Dana (RKD), dan rasio Pertumbuhan Dana Pensiun (PDP).

\section{Dana Pensiun}

Dana Pensiun adalah badan hukum yang mengelola dan menjalankan program yang menjanjikan manfaat pensiun bagi pesertanya, janda/duda/anak, yang dikaitkan dengan pencapaian usia tertentu dan memiliki status sebagai badan hukum serta memulai kegiatan sejak tanggal pengesahan oleh Menteri keuangan (Undang-Undang Nomor 11 tahun 1992 tentang Dana Pensiun). Dana pensiun terbagi menjadi 2, yaitu: 1 . Dana Pensiun Pemberi Kerja (DPPK); 2. Dana Pensiun Lembaga Keuangan (DPLK). DPPK adalah dana pensiun yang didirikan oleh orang atau badan yang mempekerjakan karyawan, dengan menyelenggarakan program pensiun manfaat pasti atau program pensiun iuran pasti bagi kepentingan sebagian atau seluruh karyawannya sebagai peserta dan yang menimbulkan kewajiban terhadap pemberi kerja, sedangkan DPLK adalah dana pensiun yang dibentuk oleh bank atau perusahaan asuransi jiwa untuk menyelenggarakan program pensiun iuran pasti bagi perorangan, baik karyawan maupun pekerja mandiri yang terpisah dari DPPK, bagi karyawan baik bank atau perusahaan asuransi jiwa yang bersangkutan (Anggraeni, 2012).

Menurut Wahab (2001), tujuan dibentuknya dana pensiun sebagai berikut:

1. untuk menarik atau memertahankan karyawan yang memiliki potensi, cer- das, terampil, dan produktif, yang diharapkan dapat meningkatkan atau mengembangkan perusahaan;

2. sebagai tanggung jawab moral dan sosial pemberi kerja kepada karyawan pada saat karyawan tidak lagi mampu bekerja atau pensiun, atau meninggal dunia;

3. untuk memberikan rasa aman bagi karyawan terhadap masa yang akan datang;

4. bagi pemerintah, akan mengurani kerawanan sosial dan menciptakan kestabilan negara;

5. dapat membiayai pembangunan nasional dalam rangka menciptakan kesejahteraan masyarakat.

Jenis program pensiun menurut UndangUndang Nomor 11 tahun 1992 tentang Dana Pensiun sebagai berikut:

1. Program Pensiun Manfaat Pasti (PPMP), yaitu program pensiun yang jumlah manfaat pensiunnya telah ditetapkan dalam peraturan dana pensiun atau program pensiun lain yang bukan merupakan program pensiun iuran pasti.

2. Program Pensiun Iuran Pasti (PPIP), yaitu program pensiun yang iurannya ditetapkan dalam peraturan dana pensiun dan seluruh iuran serta hasil pengembangannya dibukukan pada rekening masing-masing peserta manfaat pensiun.

\section{Kinerja Keuangan}

Kinerja keuangan adalah suatu analisis yang dilakukan untuk melihat sejauh mana suatu perusahaan telah melaksanakan dengan menggunakan aturan-aturan pelaksanaan keuangan secara baik dan benar (Fahmi, 2011). Penilaian kinerja setiap perusahaan berbeda-beda, tergantung kepada ruang lingkup bisnis yang dijalankan. Menurut Fahmi (2011), terdapat 5 (lima) tahap dalam melakukan analisis terhadap kinerja keuangan suatu perusahaan, yaitu: 
1. melakukan review terhadap data laporan keuangan;

2. melakukan perhitungan;

3. melakukan perbandingan terhadap hasil hitungan yang telah diperoleh;

4. melakukan penafsiran (interpretation) terhadap berbagai permasalahan yang ditemukan;

5. mencari dan memberikan penyelesaian masalah (solution) terhadap berbagai permasalahan yang ditemukan.

\section{Analisis Rasio}

Rasio dalam analisis laporan keuangan adalah angka yang menunjukkan hubungan antara suatu unsur dengan unsur lainnya dalam laporan keuangan. Hubungan antara unsur-unsur laporan keuangan tersebut dinyatakan dalam bentuk matematis yang sederhana (Jumingan, 2005).

Menurut Fahmi (2011), manfaat analisis rasio keuangan adalah:

1. sebagai alat untuk menilai kinerja dan prestasi perusahaan;

2. sebagai rujukan manajemen untuk membuat perencanaan;

3. sebagai alat untuk mengevaluasi kondisi suatu perusahaan dari perspektif keuangan;

4. bagi para kreditor, dapat digunakan untuk memperkirakan potensi resiko yang akan dihadapi dikaitkan dengan adanya jaminan kelangsungan pembayaran bunga dan pengembalian pokok pinjaman;

5. dapat dijadikan sebagai penilaian bagi pihak stakeholder organisasi.

Menurut Harahap (1998), analisis rasio mempunyai keunggulan sebagai berikut:

1. rasio merupakan angka-angka atau ikhtisar statistik yang lebih mudah dibaca dan ditafsirkan;

2. merupakan pengganti yang lebih seder- hana dari informasi yang disajikan laporan keuangan yang sangat rinci dan rumit;

3. mengetahui posisi perusahaan di tengah industri lain;

4. sebagai bahan dalam mengisi modelmodel pengambilan keputusan;

5. menstandarisasi size perusahaan.

6. lebih mudah memperbandingkan perusahaan dengan perusahaan lain atau melihat perkembangan perusahaan secara periodik atau time series;

7. lebih mudah melihat tren perusahaan serta melakukan prediksi di masa yang akan datang.

\section{Metodologi Penelitian}

Pendekatan yang digunakan dalam penelitian ini adalah pendekatan deskriptif kuantitatif. Berdasarkan tujuannya, penelitian ini termasuk dalam penelitian terapan atau applied research yaitu penelitian yang dilakukan dengan maksud menerapkan hasil temuan untuk menyelesaikan masalah (Satiti, 2013). Jenis penelitian ini adalah penelitian Studi Kasus, yaitu penelitian yang dilakukan secara langsung pada obyek yang akan diteliti.

Data yang digunakan dalam penelitian ini adalah data primer, yaitu suatu data kualitatif maupun data kuantitatif yang diperoleh dan diambil langsung pada sumber dari objek penelitian. Data yang digunakan antara lain:

1. Company Profile Dana Pensiun Universitas Surabaya;

2. Data Keuangan Dana Pensiun 1 Januari 2011 s.d 31 Desember 2016;

3. Anggaran Dana Lembaga Dana Pensiun tahun 2011 s.d 2016;

4. Laporan Posisi Portofolio Investasi Periode Januari s.d Desember 2011, 2012, 2013, 2014, 2015, dan 2016;

5. Laporan Hasil Investasi Periode 1 Januari 
s.d 31 Desember 2011, 2012, 2013, 2014, 2015, dan 2016;

6. Arahan Investasi Lembaga Dana Pensiun.

Teknik pengumpulan data yang digunakan dalam penelitian ini adalah dokumentasi, yaitu teknik pengumpulan data dengan cara mencatat, mengkopi, dan mengunduh (download) yang selanjutnya diolah sesuai dengan kebutuhan peneliti.

Pada penelitian ini akan dilakukan analisis deskriptif terhadap variabel-variabel kinerja keuangan Dana Pensiun Universitas Surabaya, yaitu:

1. Return On Investment (ROI), adalah kemampuan perusahaan dalam menghasilkan laba di masa lalu, diperoleh dengan rumus:

$$
\text { ROI }=\frac{\text { Hasil Investasi Bersih }}{\text { Rata }- \text { Rata Total Investasi }} \times 100 \%
$$

Hasil Investasi Bersih $=$ Pendapatan Investasi - Biaya Investasi Rata - Rata Investasi $=$ Rata - Rata dari Total investasi awal tahun dengan Total Investasi Akhir tahun

\section{Efisiensi Biaya Operasional (EBO),} adalah rasio untuk mengukur efisiensi dana pensiun dalam melakukan kegiatan operasional dan melakukan tugasnya sebagai pengumpul dana, menginvestasikan dan membayar manfaat pensiun kepada para peserta yang sudah masuk pada masa pensiun. EBO diperoleh dengan rumus:

$$
E B O=\frac{\text { Biaya Operasional }}{\text { Aktiva Bersih Akhir Tahun }} \times 100 \%
$$

3. Efisiensi Biaya Investasi (EBI), adalah rasio untuk mengukur efisiensi dana pensiun dalam melakukan kegiatan investasinya dalam berbagai bentuk investasi sesuai dengan arahan investasi, dan diperoleh dengan rumus:

$$
E B I=\frac{\text { Biaya Investasi }}{\text { Pendapatan Investasi }} \times 100 \%
$$

4. Pertumbuhan Dana Pensiun (PDP), adalah kemampuan dana pensiun untuk meningkatkan size yang sangat diharapkan oleh pihak internal (pengurus dana pensiun), maupun pihak eksternal (Biro Dana Pensiun). PDP dapat dihitung dengan rumus:

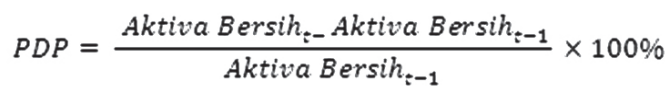

5. Rasio Kecukupan Dana (RKD), adalah perbandingan antara nilai kekayaan atau aktiva bersih dana pensiun terhadap kewajiban aktuaria. Perhitungannya sebagai berikut:

$$
R K D=\frac{\text { Jumlah Aktiva Bersih }}{\text { Kewajiban Aktuaria }} \times 100 \%
$$

(Anggraeni, 2012).

\section{Hasil Penelitian dan Pembahasan}

Dana Pensiun Universitas Surabaya merupakan pihak penyelenggara program dana pensiun Yayasan Universitas Surabaya, yang disahkan sejak tanggal 14 Juli 1997 oleh Menteri Keuangan. Sesuai dengan Keputusan Yayasan Universitas Surabaya No.045/ SK/YUS/IX/1996 tentang Pendirian Dana Pensiun Universitas surabaya, maksud pembentukan Dana Pensiun Universitas Surabaya adalah untuk menyelenggarakan Program Manfaat Pensiun Pasti dengan tujuan memberikan kesinambungan penghasilan bagi peserta dan pihak yang berhak. Dana Pensiun Universitas Surabaya termasuk Dana Pensiun Pemberi Kerja (DPPK) dengan Program Pensiun Manfaat Pasti (PPMP), dan masuk ke dalam kategori grup I dengan kepemilikan investasi di atas Rp 1 trilyun. 


\section{Analisis Arah dan Kebijakan Investasi Dana Pensiun Universitas Surabaya}

Kebijakan investasi Dana Pensiun Universitas Surabaya tertuang dalam arahan investasi yang ditetapkan oleh Yayasan Universitas Surabaya dengan berpedoman pada Peraturan Otoritas Jasa Keuangan No.3/POJK.05/2015 tanggal 31 Maret 2015, tentang Investasi Dana Pensiun, dan Peraturan Bapepam-LK No. PER-05/ BL/2012 tanggal 17 Oktober 2012 tentang Penyusunan Laporan Keuangan dan Dasar Penilaian Investasi bagi Dana Pensiun, serta SE OJK No. 9/SEOJK.05/2016 tanggal 11 April 2016 tentang Dasar Penilaian Investasi Dana Pensiun, Bentuk dan Susunan serta Tata Cara Penyampaian Laporan Investasi Tahunan Dana Pensiun.

Arahan investasi Dana Pensiun Universitas Surabaya ditetapkan berdasarkan Surat
Keputusan Yayasan Universitas Surabaya, dan kebijakan investasi yang ditetapkan sebagai berikut:

1. Hasil investasi kekayaan dana pensiun dalam 1 (satu) tahun sekurangkurangnya 10\% (sepuluh per seratus) dari total investasi, setelah dikurangi biaya investasi;

2. Jenis investasi yang dipilih dan batas maksimal untuk setiap jenis investasi terhadap total investasi dana pensiun ditetapkan sebagai berikut (lihat Tabel 1).

3. Investasi Dana Pensiun yang boleh ditanamkan pada satu pihak maksimal $20 \%$ (dua puluh per seratus) dari total Investasi Dana Pensiun;

4. Investasi penempatan langsung pada saham yang diterbitkan oleh badan hu-

Tabel 1. Kebijakan Investasi Dana Pensiun Universitas Surabaya

\begin{tabular}{|c|c|c|}
\hline No & Uraian & Maksimal \\
\hline 1 & Surat Berharga Negara & $100 \%$ \\
\hline 2 & Deposito berjangka pada bank & $100 \%$ \\
\hline 3 & Deposito on call pada bank & $100 \%$ \\
\hline 4 & Sertifikat deposito pada bank & $100 \%$ \\
\hline 5 & Saham yang tercatat di Bursa Efek & $35 \%$ \\
\hline 6 & $\begin{array}{l}\text { Penempatan langsung pada saham yang diterbitkan oleh badan hukum } \\
\text { yang didirikan berdasarkan hukum Indonesia }\end{array}$ & $15 \%$ \\
\hline 7 & Obligasi yang tercatat di Bursa Efek Indonesia & $80 \%$ \\
\hline 8 & Sukuk yang tercatat di Bursa Efek Indonesia & $80 \%$ \\
\hline 9 & Tabungan pada bank & $20 \%$ \\
\hline 10 & Efek beragun aset dari kontrak investasi kolektif efek beragun aset & $10 \%$ \\
\hline 11 & Tanah di Indonesia & \multirow{3}{*}{$15 \%$} \\
\hline 12 & Bangunan di Indonesia & \\
\hline 13 & Tanah dan Bangunan di Indonesia & \\
\hline 14 & $\begin{array}{l}\text { Unit penyertaan sebagaimana dimaksud dalam undang-undang tentang } \\
\text { pasar modal }\end{array}$ & $25 \%$ \\
\hline 15 & $\begin{array}{l}\text { Sertifikat Bank Indonesia dan atau surat berharga yang diterbitkan oleh } \\
\text { Pemerintah Republik Indonesia }\end{array}$ & $100 \%$ \\
\hline 16 & Investasi lainnya yang dikelola oleh Manajer Investasi & $60 \%$ \\
\hline
\end{tabular}

Sumber: Laporan Hasil Investasi Dana Pensiun Ubaya 
kum yang didirikan berdasarkan hukum di Indonesia, pada satu pihak tidak boleh melebihi 15\% (lima belas per seratus) dari total Investasi Dana Pensiun;

5. Investasi kekayaan Dana Pensiun yang ditanamkan dalam bentuk sertifikat deposito hanya dapat ditempatkan pada:
a. Bank Indonesia
b. Bank yang tidak terafiliasi dengan pendiri
c. Bank yang tidak menjadi penerima titipan dana pensiun.

6. Obyek-obyek investasi yang dilarang:

a. Penempatan deposito pada bank di luar negeri;

b. Penempatan langsung pada saham yang diterbitkan oleh badan hukum yang didirikan berdasarkan hukum di Indonesia, apabila pada saat penempatan perusahaan dimaksud maksimal dalam 2 (dua) tahun terakhir tidak memperoleh keuntungan;

c. Melakukan transaksi derivatif atau instrumen derivatif.

7. Pengurus wajib menyusun rencana investasi tahunan yang memuat sekurangkurangnya:
a. Rencana komposisi jenis investasi;
b. Perkiraan tingkat hasil investasi un- tuk masing-masing jenis investasi;
c. Pertimbangan yang mendasari ren- cana komposisi jenis investasi yang dipilih.

8. Pengurus harus menjaga likuiditas minimal portofolio investasi dana pensiun pada periode 1 (satu) bulan. Likuiditas minimal tersebut ditetapkan sebesar 2\% (dua per seratus) dari total investasi atau sejumlah pembayaran manfaat pensiun.

Arahan dan kebijakan investasi di atas dimaksudkan agar pengurus dalam menjalankan pengelolaan dana pensiun tetap berdasar pada Undang-Undang Dana Pen- siun ke dalam jenis-jenis investasi yang ideal, sehingga diharapkan portofolio yang dipilih adalah yang paling aman sekaligus menguntungkan untuk pengembangan kekayaan dana pensiun.

Alokasi pada jenis-jenis investasi dengan portofolio investasi yang dilakukan pengurus pada setiap tahun telah memenuhi ketentuan perundangan. Rincian portofolio investasi dapat dilihat pada Tabel 2.

Dari Tabel 2 dapat diketahui besarnya proporsi untuk masing-masing investasi tidak melebihi arahan dan kebijakan investasi pada setiap tahun. Menurut opini audit, semua portofolio investasi telah disajikan secara wajar dalam semua hal yang material. Berikut disajikan dalam grafik jenis investasi yang memiliki prosentase terbesar selama periode 2011 sampai dengan 2016.

Menurut Gambar 1, pada setiap tahun Dana Pensiun Ubaya menempatkan jumlah terbesar pada investasi obligasi, yaitu rata-rata sebesar 53\%. Hal ini disebabkan investasi pada obligasi masih memberikan tingkat return yang lebih besar daripada investasi yang lainnya.

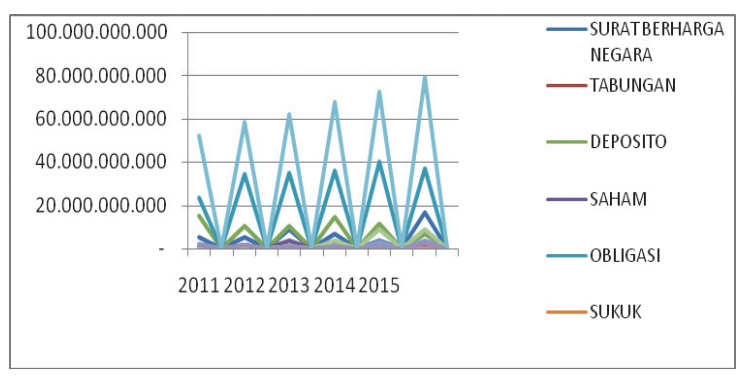

Gambar 1. Grafik Alokasi Investasi

\section{Analisis Kinerja Hasil Investasi}

Menurut peraturan 0JK Nomor 3/POJK. 05/2015, pada pasal 24, menyebutkan bahwa dewan pengawas wajib mengevaluasi kinerja investasi dana pensiun paling sedikit 2 (dua) kali dalam 1 (satu) tahun buku. Evaluasi kinerja investasi didasarkan pada: 
1. Laporan investasi tahunan dan hasil pemeriksaan akuntan publik atas laporan investasi tahunan;

2. Pendapat dan saran peserta kepada pendiri, dewan pengawas, dan pengurus mengenai perkembangan portofolio dan hasil kekayaan dana pensiun.

Berikut adalah hasil investasi dari Dana Pensiun Universitas Surabaya periode tahun 2011 sampai dengan 2016 (lihat Tabel 3).

Dari Tabel 3 dapat diketahui bahwa hasil investasi selama tahun 2011 sampai dengan 2016 memberikan hasil yang cukup stabil. Meskipun terdapat target yang tidak tercapai pada tahun 2013, 2014, 2015, dan 2016, secara keseluruhan dapat dinilai baik, karena pada setiap tahun, Dana Pensiun (Dapen) Ubaya masih mengalami surplus, yang dilihat dari kenaikan jumlah aset neto. Pada tahun 2013, tidak tercapainya target investasi disebabkan karena kondisi perekonomian Indonesia yang mengalami penurunan. Terdapat penurunan pertumbuhan investasi di sektor riil sebesar $7 \%$, penurunan harga komoditi, kenaikan bahan bakar, melemahnya nilai tukar rupiah, dan defisit pada neraca perdagangan. Sedangkan pada tahun 2014, meskipun target tidak tercapai, namun hasil investasi meningkat dibandingkan tahun 2012. Hal ini disebabkan karena terjadi peningkatan dalam aset neto, peningkatan suku bunga deposito, harga pasar obligasi, serta surat berharga pemerintah. Pada tahun 2015, kinerja investasi juga mengalami penurunan. Penyebabnya adalah menurunnya tingkat suku bunga Bank Indonesia, yang sangat berdampak pada pasar modal. Pada tahun 2016, target investasi juga belum tercapai. Namun, aset neto meningkat, dan kualitas pendanaan adalah baik.

Tabel 2. Alokasi Investasi

\begin{tabular}{|c|c|c|c|c|c|c|c|c|c|c|c|c|c|}
\hline \multirow{2}{*}{ No } & \multirow{2}{*}{ JENIS INVESTASI } & \multicolumn{2}{|l|}{2011} & \multicolumn{2}{|c|}{2012} & \multicolumn{2}{|l|}{2013} & \multicolumn{2}{|l|}{2014} & \multicolumn{2}{|l|}{2015} & \multicolumn{2}{|l|}{2016} \\
\hline & & Rupiah & $\%$ & Rupiah & $\%$ & Rupiah & $\%$ & Rupiah & $\%$ & Rupiah & $\%$ & Rupiah & $\%$ \\
\hline 1 & SURAT BERHARGA NEGARA & 5.337 .500 .000 & $10,30 \%$ & 5.452 .500 .000 & $9,37 \%$ & 8.757 .500 .000 & $14,20 \%$ & 6.827 .500 .000 & $10,12 \%$ & 3.842 .000 .000 & $5,32 \%$ & 16.667 .926 .415 & $21,10 \%$ \\
\hline 2 & TABUNGAN & 5.819 .017 & $1,69 \%$ & 1.420 .136 .685 & $2,44 \%$ & 413.022 .391 & $0,67 \%$ & 1.349 .899 .802 & $2,00 \%$ & 298.590 .595 & $0,41 \%$ & 1.871 .059 .229 & $2,37 \%$ \\
\hline 3 & DEPOSITO & .400 .000 .000 & $29,71 \%$ & 10.500 .000 .000 & $8,04 \%$ & 0.600 .000 .000 & $17,19 \%$ & 4.850 .000 .000 & $22,00 \%$ & 1.500 .000 .000 & $15,93 \%$ & 7.000 .000 .000 & $86 \%$ \\
\hline 4 & SAHAM & 325.848 .120 & $2,56 \%$ & 325.848 .120 & $28 \%$ & 3.655 .088 .194 & $5,93 \%$ & 1.974 .607 .433 & $2,93 \%$ & 3.154 .576 .791 & $4,37 \%$ & 1.207 .310 .710 & $1,53 \%$ \\
\hline 5 & OBLIGAS: & .433 .000 .000 & $45,20 \%$ & 34.218 .500 .000 & $58,80 \%$ & \begin{tabular}{|l|l}
35.073 .000 .000 \\
\end{tabular} & $56,87 \%$ & 6.014 .000 .000 & $53,36 \%$ & 40.089 .500 .000 & $55,52 \%$ & 36.751 .064 .350 & $46,52 \%$ \\
\hline 6 & SUKUK & 705.600 .000 & $1,36 \%$ & - & $0,00 \%$ & 8 & $0,00 \%$ & - & $0,00 \%$ & - & $0,00 \%$ & - & $0,00 \%$ \\
\hline 7 & REKSADA & 2.096 .591 .985 & $4,04 \%$ & 1.641.189.375 & $2,82 \%$ & 000.000 & $1,46 \%$ & 00.000 .000 & $2,52 \%$ & 099.502 .488 & $4,29 \%$ & 746.271 .212 & $4,74 \%$ \\
\hline 8 & TANAH & 963.000 .000 & $1,86 \%$ & 963.000 .000 & $1,65 \%$ & - & $0,00 \%$ & -1 & $0,00 \%$ & - & $0,00 \%$ & - & $0,00 \%$ \\
\hline 9 & PENEMPAT & & $0,00 \%$ & 5.000 .000 & $1,68 \%$ & 000.000 & $1,58 \%$ & 5.000 .000 & $5,15 \%$ & .000 & $12,36 \%$ & .000 & $11,30 \%$ \\
\hline 10 & TANAH\& & .000 .000 & $3,28 \%$ & 0.000 .000 & $2,92 \%$ & 03.000 .000 & $2,11 \%$ & 1.303 .000 .000 & $1,93 \%$ & 3.000 .000 & $1,80 \%$ & 2.836 .000 .000 & $3,59 \%$ \\
\hline & JUMLAH & \begin{tabular}{|l|}
51.837 .359 .122 \\
\end{tabular} & $100,00 \%$ & 58.196 .174 .180 & $100,00 \%$ & 61.676 .610 .585 & $100,00 \%$ & \begin{tabular}{|l|}
67.494 .007 .235 \\
\end{tabular} & $100,00 \%$ & 72.212.169.874 & $100,00 \%$ & 79.004.631.916 & $100,00 \%$ \\
\hline
\end{tabular}

Sumber: data diolah dari Laporan Keuangan Dana Pensiun Ubaya

Tabel 3. Hasil Investasi dan Realisasi Pencapaian

\begin{tabular}{|c|c|c|c|c|}
\hline TAHUN & HASIL INVESTASI BERSIH (Rp) & TARGET & REALISASI & KETERANGAN \\
\hline 2011 & 5.172 .373 .811 & $10,18 \%$ & $11,03 \%$ & Tercapai \\
\hline 2012 & 6.047 .896 .345 & $10,29 \%$ & $12,54 \%$ & Tercapai \\
\hline 2013 & 5.771 .560 .186 & $10,15 \%$ & $9,45 \%$ & Tidak Tercapai \\
\hline 2014 & 6.016 .062 .612 & $10,42 \%$ & $9,45 \%$ & Tidak Tercapai \\
\hline 2015 & 5.443 .473 .230 & $10,48 \%$ & $7,92 \%$ & Tidak Tercapai \\
\hline 2016 & 7.071 .584 .225 & $10,00 \%$ & $9,18 \%$ & Tidak Tercapai \\
\hline
\end{tabular}

Sumber: Data diolah dari Laporan Keuangan Dana Pensiun Ubaya 


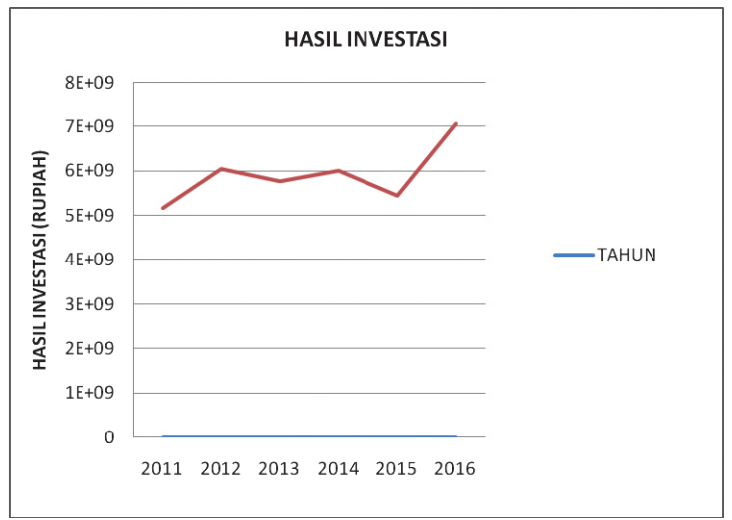

Gambar 2. Grafik Hasil Investasi

\section{Analisis Rasio Keuangan}

\section{Return On Investment (ROI)}

ROI adalah rasio yang mengukur kemampuan perusahaan di dalam menghasilkan laba bersih berdasarkan tingkat asset tertentu (Hanafi \& Halim, 2009). ROI melihat sejauh mana investasi yang telah ditanamkan mampu memberikan pengembalian keuntungan sesuai dengan yang diharapkan (Fahmi, 2011). Semakin tinggi ROI, maka dapat dikatakan semakin baik kinerja manajemen di dalam menghasilkan tingkat laba. Berikut disajikan hasil perhitungan
ROI dari DAPEN Ubaya.

Dari Tabel 4 dapat dilihat bahwa periode tahun 2011 sampai dengan 2016, rasio ROI mengalami penurunan. Sesuai dengan analisis pada hasil investasi, penurunan ROI ini disebabkan karena memang terjadi penurunan terhadap hasil investasi oleh karena faktor perekonomian secara makro.

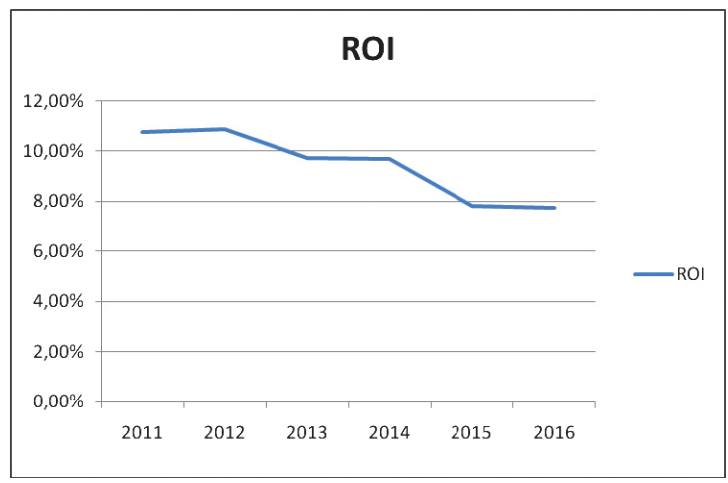

\section{Gambar 3. Grafik Perkembangan ROI}

\section{Efisiensi Biaya Operasional}

Biaya operasional adalah faktor yang penting di dalam dana pensiun (Bikker \& Dreu, 2006). Biaya akan mengurangi tingkat hasil investasi yang dapat mengurangi jum-

Tabel 4. Perhitungan Return On Investment (ROI)

\begin{tabular}{|l|r|r|r|r|r|r|}
\multirow{2}{*}{ KETERANGAN } & \multicolumn{7}{c|}{ TAHUN } \\
\cline { 2 - 7 } & \multicolumn{1}{|c|}{$\mathbf{2 0 1 1}$} & \multicolumn{1}{c|}{$\mathbf{2 0 1 2}$} & \multicolumn{1}{c|}{$\mathbf{2 0 1 3}$} & $\mathbf{2 0 1 4}$ & \multicolumn{1}{c|}{$\mathbf{2 0 1 5}$} & \multicolumn{1}{c|}{$\mathbf{2 0 1 6}$} \\
\hline HASIL INVESTASI BERSIH (Rp) & 5.165 .669 .150 & 5.990 .572 .448 & 5.740 .139 .584 & 6.129 .454 .013 & 5.435 .782 .543 & 5.873 .112 .348 \\
\hline TOTAL INVESTASI AWAL (Rp) & 44.039 .108 .485 & 51.837 .359 .122 & 58.239 .971 .060 & 59.668 .812 .837 & 66.648 .171 .690 & 72.333 .475 .124 \\
\hline TOTAL INVESTASI AKHIR (Rp) & 51.837 .359 .122 & 58.239 .971 .060 & 59.668 .812 .837 & 66.648 .171 .690 & 72.333 .475 .124 & 79.004 .631 .916 \\
\hline RATA2 TOTAL INVESTASI (Rp) & 47.938 .233 .804 & 55.038 .665 .091 & 58.954 .391 .949 & 63.158 .492 .264 & 69.490 .823 .407 & 75.669 .053 .520 \\
\hline ROI & $\mathbf{1 0 , 7 8 \%}$ & $\mathbf{1 0 , 8 8 \%}$ & $\mathbf{9 , 7 4 \%}$ & $\mathbf{9 , 7 0 \%}$ & $\mathbf{7 , 8 2 \%}$ & $\mathbf{7 , 7 6 \%}$ \\
\hline
\end{tabular}

Sumber: Data diolah dari Laporan Keuangan Dana Pensiun Universitas Surabaya

Tabel 5. Rekapitulasi Efisiensi Biaya Operasional (EBO)

\begin{tabular}{|l|r|r|r|r|r|r|}
\multirow{2}{*}{ KETERANGAN } & \multicolumn{6}{c|}{ TAHUN } \\
\cline { 2 - 7 } & \multicolumn{1}{c|}{$\mathbf{2 0 1 1}$} & \multicolumn{1}{c|}{$\mathbf{2 0 1 2}$} & \multicolumn{1}{c|}{$\mathbf{2 0 1 3}$} & \multicolumn{1}{c|}{$\mathbf{2 0 1 4}$} & \multicolumn{1}{c|}{$\mathbf{2 0 1 5}$} \\
\hline BIAYA OPERASIONAL (Rp) & 451.566 .061 & 417.414 .737 & 467.683 .967 & 499.609 .057 & 580.179 .180 & 618.602 .835 \\
\hline ASET BERSIH AKHIR TAHUN (RP & 52.335 .282 .890 & 58.381 .457 .597 & 60.435 .844 .890 & 67.827 .245 .168 & 73.801 .429 .874 & 80.995 .018 .648 \\
\hline EBO & $\mathbf{0 , 8 6 \%}$ & $\mathbf{0 , 7 1 \%}$ & $\mathbf{0 , 7 7 \%}$ & $\mathbf{0 , 7 4 \%}$ & $\mathbf{0 , 7 9 \%}$ & $\mathbf{0 , 7 6 \%}$ \\
\hline
\end{tabular}

Sumber : Data diolah dari Laporan Keuangan Dana Pensiun Universitas Surabaya 
lah manfaat pensiun yang akan dibayarkan. Maka, jika biaya operasional semakin besar, akan mengurangi hasil pengembangan dana, yaitu jumlah manfaat pensiun. Berikut ini adalah hasil perhitungan rasio EBO (lihat Tabel 5).

Dari Tabel 5 diketahui bahwa rasio EBO mengalami penurunan. Hal tersebut menunjukkan bahwa telah terjadi efisiensi biaya di dalam pengelolaan keuangan Dana Pensiun Ubaya.

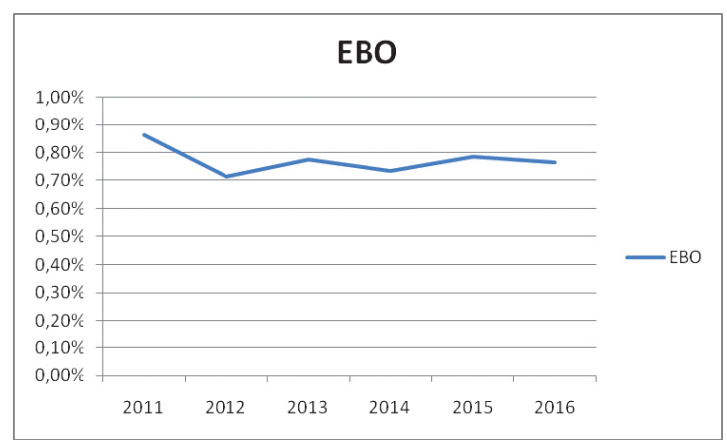

\section{Gambar 5. Grafik Perkembangan EBO}

\section{Efisiensi Biaya Investasi (EBI)}

Biaya investasi adalah biaya yang terjadi pada saat dana pensiun melakukan kegiatan investasi dari iuran yang sudah diterima pada bentuk investasi yang diperbolehkan dalam arahan investasinya. Jika biaya investasi terlalu besar, akan mengarah pada pemborosan dan akan mengurangi hasil pengembangan. Biaya investasi terdiri atas biaya provisi dan biaya komisi (Kadarisman \& Wahyuni, 2010). Berikut adalah tabel perhitungan dari rasio EBI (lihat Tabel 6).

Dari Tabel 6 diketahui bahwa rasio EBI mengalami peningkatan. Hal tersebut menunjukkan bahwa telah terjadi ketidakefisienan dalam melakukan pengeluaran biaya. Penyebabnya adalah karena peningkatan nilai investasi yang dilakukan dana pensiun, sehingga menimbulkan biaya yang semakin besar.

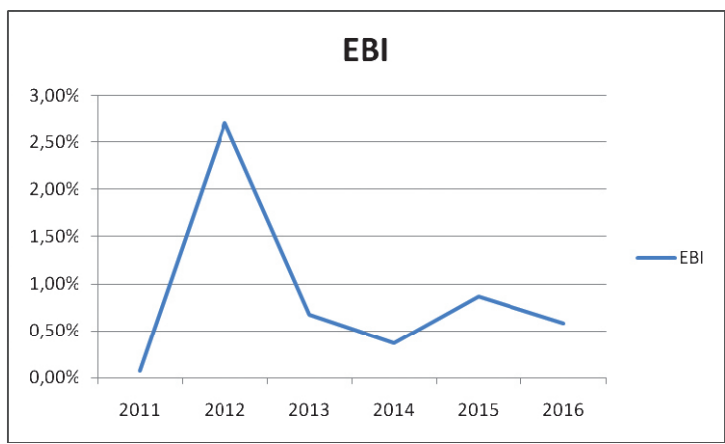

Gambar 6. Grafik Perkembangan EBO

4. Rasio Kecukupan Dana (RKD)

Rasio Kecukupan Dana (RKD) adalah perbandingan antara nilai kekayaan atau aktiva bersih dana pensiun terhadap kewajiban aktuaria. Semakin tinggi rasio, akan menunjukkan kualitas pendanaan yang dilakukan oleh dana pensiun. Berikut adalah perhitungan rasio kecukupan dana (lihat Tabel 7).

Dari Tabel 7 diketahui bahwa rasio kecukupan dana Dana Pensiun Ubaya menunjukkan kualitas 1 (satu). Semakin tinggi rasio ini akan menunjukkan kinerja keuangan yang semakin baik. Meskipun terjadi penurunan pada tahun 2015 dan 2016, jumlah aset neto (aktiva bersih) mengalami peningkatan yang significant.

Tabel 6. Rekapitulasi Efisiensi Biaya Investasi (EBI)

\begin{tabular}{|c|c|c|c|c|c|c|}
\hline \multirow{2}{*}{ KETERANGAN } & \multicolumn{6}{|c|}{ TAHUN } \\
\hline & 2011 & 2012 & 2013 & 2014 & 2015 & 2016 \\
\hline BIAYA INVESTASI (Rp) & 3.952 .150 & 166.333 .896 & 39.103 .999 & 22.969 .355 & 47.843 .351 & 34.585 .169 \\
\hline PENDAPATAN INVESTASI (Rp) & 5.169 .621 .300 & 6.156.906.344 & 5.779 .243 .583 & 6.152 .423 .368 & 5.483 .625 .894 & 5.907 .697 .517 \\
\hline EBI & $0,08 \%$ & $2,70 \%$ & $0,68 \%$ & $0,37 \%$ & $0,87 \%$ & $0,59 \%$ \\
\hline
\end{tabular}

Sumber: Data diolah dari Laporan Keuangan Dana Pensiun Universitas Surabaya 


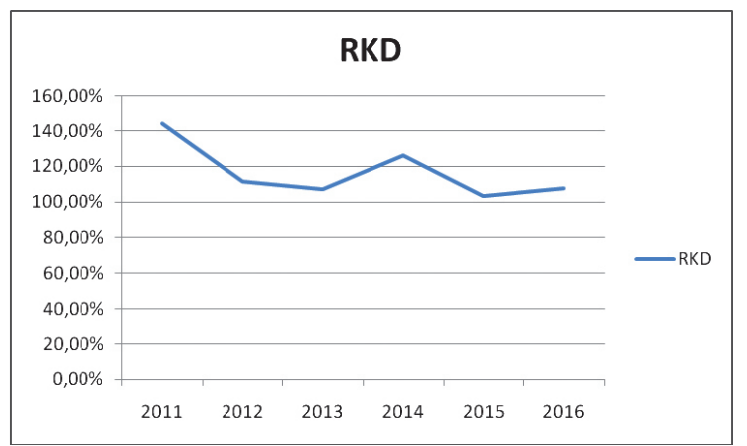

Gambar 7. Grafik Perkembangan EBO

Berikut adalah rekapitulasi rasio keuangan dari Dana Pensiun Ubaya (lihat Tabel 8).

Dari Tabel 8 dapat dilihat bahwa kinerja keuangan dari Dana Pensiun Universitas Surabaya adalah baik. Rasio ROI mengalami peningkatan, meskipun biaya efisiensi mengalami peningkatan. Rasio RKD menunjukkan bahwa pendanaan berada dalam kualitas pendanaan 1 (satu).

\section{Simpulan}

Dana Pensiun Universitas Surabaya merupakan pihak penyelenggara program dana pensiun Yayasan Universitas Surabaya, yang disahkan sejak tanggal 14 Juli 1997 oleh Menteri Keuangan. Dana Pensiun Universitas Surabaya termasuk Dana Pensiun Pemberi Kerja (DPPK) dengan Program Pensiun Manfaat Pasti (PPMP), dan masuk ke dalam kategori grup I dengan kepemilikan investasi di atas Rp 1 trilyun.

Besarnya proporsi untuk masingmasing investasi tidak melebihi arahan dan kebijakan investasi pada setiap tahun. Menurut opini audit, semua portofolio investasi telah disajikan secara wajar dalam semua hal yang material.

Hasil investasi selama tahun 2011 sampai dengan 2016 memberikan hasil yang cukup stabil. Meskipun terdapat target yang tidak tercapai pada tahun 2013, 2014, 2015, dan 2016, secara keseluruhan dapat dinilai baik, karena pada setiap tahun, Dapen Ubaya masih mengalami surplus, yang dilihat dari kenaikan jumlah aset neto.

Dari analisis rasio keuangan dapat dilihat bahwa kinerja keuangan dari Dana Pensiun Ubaya adalah baik. Rasio ROI mengalami peningkatan, meskipun biaya efisiensi mengalami peningkatan. Rasio RKD menunjukkan bahwa pendanaan berada dalam kualitas pendanaan 1 (satu).

\section{Tabel 7. Rekapitulasi Rasio Kecukupan Dana (RKD)}

\begin{tabular}{|l|r|r|r|r|r|r|}
\multirow{2}{*}{ KETERANGAN } & \multicolumn{6}{c|}{ TAHUN } \\
\cline { 2 - 7 } \multicolumn{1}{c|}{} & \multicolumn{1}{|c|}{$\mathbf{2 0 1 1}$} & \multicolumn{1}{c|}{$\mathbf{2 0 1 2}$} & \multicolumn{1}{c|}{$\mathbf{2 0 1 3}$} & \multicolumn{1}{c|}{$\mathbf{2 0 1 5}$} & \multicolumn{2}{c|}{$\mathbf{2 0 1 6}$} \\
\hline KEWAJIBAN AKTUARIA (Rp) & $36.364 .084 .971,00$ & 48.557 .240 .300 & 54.057 .084 .300 & 57.845 .330 .000 & 72.936 .318 .544 & 75.223 .161 .000 \\
\hline AKTIVA BERSIH AKHIR (Rp) & 52.335 .282 .890 & 54.057 .084 .300 & 57.845 .330 .000 & 72.936 .318 .544 & 75.223 .161 .000 & 80.995 .018 .648 \\
\hline RKD & $\mathbf{1 4 3 , 9 2 \%}$ & $\mathbf{1 1 1 , 3 3 \%}$ & $\mathbf{1 0 7 , 0 1 \%}$ & $\mathbf{1 2 6 , 0 9 \%}$ & $\mathbf{1 0 3 , 1 4 \%}$ & $\mathbf{1 0 7 , 6 7 \%}$ \\
\hline
\end{tabular}

Sumber: Data diolah dari Laporan Keuangan Dana Pensiun Universitas Surabaya

Tabel 8. Rekapitulasi Rasio

\begin{tabular}{|r|r|r|r|r|r|r|}
\hline \multirow{2}{*}{ RASIO } & \multicolumn{7}{|c|}{ TAHUN } \\
\cline { 2 - 7 } & $\mathbf{2 0 1 1}$ & $\mathbf{2 0 1 2}$ & $\mathbf{2 0 1 3}$ & $\mathbf{2 0 1 4}$ & \multicolumn{1}{c|}{$\mathbf{2 0 1 5}$} & \multicolumn{1}{c|}{$\mathbf{2 0 1 6}$} \\
\hline ROI & $10,78 \%$ & $10,88 \%$ & $9,74 \%$ & $9,70 \%$ & $7,82 \%$ & $7,76 \%$ \\
\hline EBO & $0,86 \%$ & $0,71 \%$ & $0,77 \%$ & $0,74 \%$ & $0,79 \%$ & $0,76 \%$ \\
\hline EBI & $0,08 \%$ & $2,70 \%$ & $0,68 \%$ & $0,37 \%$ & $0,87 \%$ & $0,59 \%$ \\
\hline RKD & $143,92 \%$ & $111,33 \%$ & $107,01 \%$ & $126,09 \%$ & $103,14 \%$ & $107,67 \%$ \\
\hline
\end{tabular}

Sumber: Data diolah dari Laporan Keuangan Dana Pensiun Universitas Surabaya 


\section{Daftar Pustaka}

Ambachtsheer, K. R. Capelle dan T.Scheibelhut. 1998. "Improving Pension Fund Performance”. Financial Analysis Journal, Vol 54:15-21.

Amman, M. Dan A. Zingg. 2010. "Performance and Governance of Swiss Pension Fund". Journal of Pension Economics \& Finance, 9:95-128.

Anggraeni, Kurnia Agustina. 2012. "Analisis Kinerja Keuangan dan Rasio Kecukupan Dana pada Dana Pensiun Pemberian Kerja Manfaat Pasti di Indonesia". Jurnal Ilmu \& Riset Akuntansi, Vol.1, No.11.

Fahmi, Irham. 2011. Analisis Laporan Keuangan. Bandung: Alfabeta.

Jumingan. 2014. Analisis Laporan Keuangan. Jakarta: Bumi Aksara.

Wahab, Zulaini. 2001. Dana Pensiun dan Jaminan Sosial Tenaga Kerja di Indonesia. Bandung: Citra Aditya Bakti.

Undang-Undang Nomor 11 Tahun 1992 tentang Dana Pensiun.

Peraturan 0JK Nomor 3/POJK.05/2015 tentang Investasi Dana Pensiun.

Surat Edaran OJK Nomor 9/SEOJK.05/2016 tentang Dasar Penilaian Investasi Dana Pensiun dan Susunan serta Tata Cara Penyampaian Laporan Investasi Tahunan Dana Pensiun. 